\title{
Honey bee visitation to sunflower: effects on pollination and plant genotype
}

\author{
Emerson Dechechi Chambó ${ }^{1}$, Regina Conceição Garcia ${ }^{2 *}$, Newton Tavares Escocard de Oliveira ${ }^{2}$, \\ José Barbosa Duarte-Júnior ${ }^{2}$ \\ ${ }^{1}$ UNIOESTE - Programa de Pós-Graduação em Zootecnia. \\ ${ }^{2}$ UNIOESTE/Centro de Ciências Agrárias, R. Pernambuco, 1777 - 85960-000 - Marechal Cândido Rondon, PR - Brasil. \\ *Corresponding author<re_conbr@yahoo.com.br> \\ Edited by: Richard V. Glatz / Cláudio Marcelo Gonçalves de Oliveira
}

\begin{abstract}
Sunflower (Helianthus annuus L.) is an allogamic plant, which needs insects on flowering, especially the honeybees for seed production. Collecting nectar and pollen by honeybees in agricultural crops is essential to apiculture, as well as a better understanding of plant biology. The foraging behavior of Africanized Apis mellifera L. (Hymenoptera, Apidae) and its efficiency of pollination on seed yield of sunflower genotypes (open pollination and restricted pollination) were evaluated. There were peaks of visits by $A$. mellifera for nectar collection on the $2^{\text {nd }}$ and $3^{\text {rd }}$ flowering days between $7 \mathrm{~h} 00$ and $8 \mathrm{~h} 30$. The average density of $A$. mellifera during increased visitation ranged from 2.27 to 2.94 bees per capitulum. Nectar collecting bees were more frequent (2.28 bees per capitulum) than pollen collecting ( 0.40 bees per capitulum). On the $3^{\text {rd }}$ flowering day, Helio 360 and Aguará hybrids had higher $(p \leq 0.05)$ number of bee visits per flower head than the other genotypes. Seed yield was $43 \%$ higher $(p \leq 0.05)$ from sunflower plants that were visited by pollinator-insects compared with plants restricted to pollinators.

Keywords: Apis mellifera, pollinators, floral resources, yield
\end{abstract}

\section{Introduction}

Sunflower (Helianthus annuus L.) has important agronomic characteristics, such as resistance to drought, cold and heat. Sunflower cultivation is an important economic alternative in crop rotation and provides intercropping and succession of crops in seed-producing regions (Porto et al., 2007).

The morphophysiological disagreement of stamens and pistils, breeding system of self-incompatibility and pollen not well adapted to the transport by wind hinder the process of pollination by anemophily (Vrânceanu, 1977). The floral arrangement and sequence of flower opening allows them to be assisted when visited by pollinating insects (McGregor, 1976; Free, 1993). Bees are the most important insects in the sunflower pollination process (Morgado et al., 2002). Unlike other insects that visit flowers only for their own food, bees visit a greater number of flowers to fulfill the needs of their colony (Müller et al., 2006).

The foraging pattern of bees on sunflower flowers is a key issue in studies of pollination (DeGrandi-Hoffman and Martin, 1995; Santana et al., 2002). Pollination is an essential requirement for successful beekeeping, providing a greater understanding of plant biology and increased production (Thomazini and Thomazini, 2002).

This study aimed at observing the food collection behavior (nectar and pollen) of Africanized honey bees on sunflower genotypes at different times of the day during flowering and to estimate the yield of seeds resulting from the action of pollinators in sunflower cultivation.

\section{Materials and Methods}

The experiments were conducted in Marechal Cândido

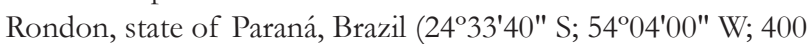

$m$ a.s.l.). Sunflower crop flowered between 22 and 26 Dec. 2008. The experimental area ( $30 \mathrm{~m}$ long, $27 \mathrm{~m}$ wide and $672 \mathrm{~m}^{2}$ ) was surrounded by soybean crops and it was approximately $3.2 \mathrm{~km}$ far eastward from a riparian vegetation remnant. Data on climatic conditions were collected in Dec., during flowering. During flowering, rainfall was $1.8 \mathrm{~mm}, 26{ }^{\circ} \mathrm{C}$ average temperature, $65 \%$ relative humidity and $2 \mathrm{~m} \mathrm{~s}^{-1}$ average wind speed.

The experiment was established in a no-tillage system and maize was the previous crop grown. The 10-20-20 NPK fertilizer was used at $425 \mathrm{~kg} \mathrm{ha}^{-1}$. Five commercial self-fertile sunflower cultivars were used in the study and each cultivar had a single capitulum per plant. Cultivars used were Multissol variety (Coordination of Integral Technical Assistance - Cati SP), hybrids Aguará and Charrua (Atlantica Seeds LTDA) and Helio 360 and Helio 251 (Helianthus annuus L. LTDA) and were sown on 10 Oct. 2008 in 20 plots, $33.6 \mathrm{~m}^{2}$ each. Seeds were sown in eight rows $0.70 \mathrm{~m}$ apart, with spacing between plants in rows of 0.30 $\mathrm{m}$. The sowing depth was $0.03 \mathrm{~m}$. After 20 days of emergency thinning was performed leaving one plant per hole.

Two Langstroth-model hives with $A$. mellifera Africanized bees - stable population and devoid of supers (strong colonies) - were introduced before the flowering period. Both colonies were located in the central part of each plat width but in opposite directions in the experimental area.

Before flowering, two plants of each genotype (Helio 360, Helio 251, Charrua, Aguará and Multissol) were tagged with strip in each experimental unit, with four replications, totaling 40 observations. In the plant picking process, it was especially careful about choosing plants with diameters of capitulum that were approximately the same as the ones in each parcel. Four time intervals were determined for observations: from $7 \mathrm{~h} 00$ to $8 \mathrm{~h} 30,9 \mathrm{~h} 30$ to $11 \mathrm{~h} 00,13 \mathrm{~h} 00$ to $14 \mathrm{~h} 30$ and $15 \mathrm{~h} 30$ to $17 \mathrm{~h} 00$. After the flower head and early anthesis have opened, data were 
collected for five consecutive days. Records of the total number of bees on each capitulum (regardless of food collecting or visit duration) and the type of reward collected by each bee (nectar or pollen) were visually recorded by an observer who spent two minutes for each plant. In this study, we only recorded data from A. mellifera and ignored other floral visitors.

The experimental design was complete randomized block in split plot divided into time with 100 treatments, four replications and two plants per experimental unit. Treatments were a combination of five sunflower genotypes (Helio 360, Helio 251, Charrua, Aguará and Multissol) allocated in plots and five days of observation versus four time intervals arranged in the subplots. Randomized blocks were used to reduce the heterogeneous conditions of site, as the proximity of colonies to plants may favor certain genotypes.

Data on the number of total visits of $A$. mellifera, the number collecting nectar and/or pollen were subjected to analysis of residuals normality using the Shapiro-Wilk test at $5 \%$ probability. Data for total number of visits by $A$. mellifera $(\mathrm{VT})$, visits of nectar collectors (CN) and/or pollen collectors (CP) had normalized residuals when transformed using the expression (VT + $0.5)^{1 / 2},(\mathrm{CN}+0.5)^{1 / 2} \mathrm{e}(\mathrm{CP}+0.5)^{1 / 2}$, respectively. The effects of genotype, flowering day and time of visitation were verified by analysis of variance (linear models). The effect of flowering day and time of visitation was analyzed using regression equations. The effect of genotype was compared using the adjusted TukeyKramer test. All analyses assumed $5 \%$ significance level.

Before flowering 20 plants of each genotype, with approximately equal capitula diameters were randomly chosen from the usable area of each plot. Ten bagged and ten open capitula were sampled from each cultivar. Seed yield per treatment was estimated for a harvest standard adjusted to 45.000 plants $\mathrm{ha}^{-1}$. The moisture content of seeds was determined by the oven method at $105^{\circ} \mathrm{C} \pm 30{ }^{\circ} \mathrm{C}$ for $24 \mathrm{~h}$, with two replicates of each experimental unit (Brazil, 2004). The seeds data was further transformed to $11 \%$ standard humidity according to Campos and Sader (1987).

The experimental design was performed by complete randomized blocks in split plot divided into times with ten treatments, four replications and ten plants per experimental unit. Treatments were a combination of five sunflower genotypes (Helio 360, Helio 251, Charrua, Aguará and Multissol) allocated in plots and two test by pollination (open pollination and restricted pollination) arranged in the subplots. Yield data were compared by analysis of variance and the pollination effect was verified by $\mathrm{F}$ test, both with $5 \%$ significance level. Statistical analysis was performed using the Statistical and Genetic Analysis System - SAEG (UFV, 2003).

\section{Results}

There was interaction $(p \leq 0.05)$ sunflower genotype by flowering day on the number of $A$. mellifera nectar collectors (Figure 1). There was no interaction $(p>0.05)$ sunflower genotype by flowering day on the number of $A$. mellifera pollen collectors. Higher numbers of $A$. mellifera nectar collectors occurred during 2.93 days (Helio 360), 3.00 (Aguará), 2.96 (Charrua), 3.04 (Helio 251) and 2.77 (Multissol) after early flowering (Figure 1). There were effects $(p \leq$
0.05) of the interaction time interval by flowering day on the number of A. mellifera nectar (Figure 2) and pollen (Figure 3) collector. The highest number of nectar and pollen collector bees occurred in the morning between $7 \mathrm{~h} 00$ to $8 \mathrm{~h} 30$ and less in the period $9 \mathrm{~h} 30$ to $11 \mathrm{~h} 00$. Between $13 \mathrm{~h} 00$ to $14 \mathrm{~h} 30$, there was a further decrease in the number of visits over the previous time interval, increasing again with period $15 \mathrm{~h} 30$ to $17 \mathrm{~h} 00$ (Figures 2, 3).

Estimated regression equations based on 40 observations about the number of total visits of $A$. mellifera regardless of the type of food collected by these bees and the genotype studied at each time interval in their respective days with highest number of visits were: $\hat{Y}_{1}=-50.89+$ $114.18 \mathrm{X}-19.36 \mathrm{X}^{2}$ (maximum day $\left.=2.95\right) . \hat{Y}_{2}=-68.42+$ $114.18 X-19.36 X^{2}$ (maximum day $\left.=2.95\right) . \hat{Y}_{3}=-77.62+$ $114.18 \mathrm{X}-19.36 \mathrm{X}^{2}$ (maximum day $=2.95$ ) and $\hat{Y}_{4}=-50.89$

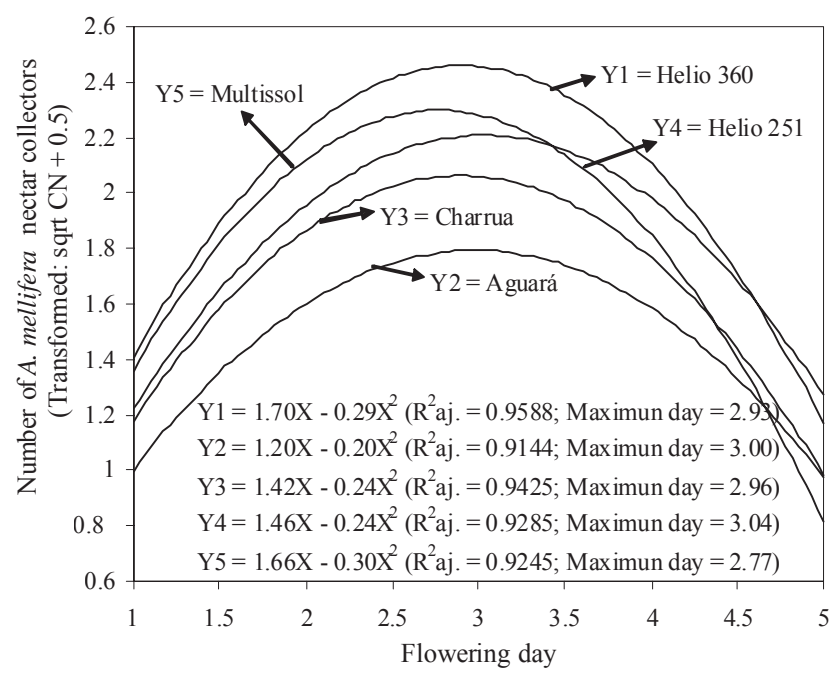

Figure 1 - Regression curves of the total number of $A$. mellifera nectar collectors as a function of sunflower flowering day for each genotype.

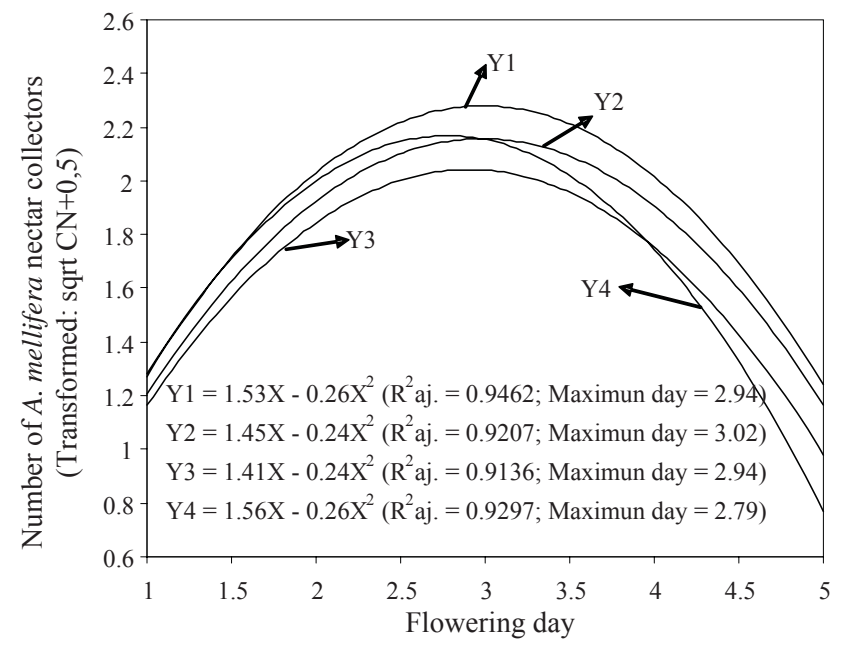

Figure 2 - Regression curves of the total number of $A$. mellifera nectar collectors (Y1, Y2, Y3 and Y4) as a function of sunflower flowering day for each time interval ( $7 \mathrm{~h} 00$ to $8 \mathrm{~h} 30 ; 9 \mathrm{~h} 30$ to $11 \mathrm{~h} 00 ; 13 \mathrm{~h} 00$ to $14 \mathrm{~h} 30$; and $15 \mathrm{~h} 30$ to $17 \mathrm{~h} 00)$. 
$+106.63 \mathrm{X}-19.36 \mathrm{X}^{2}$ (maximum day $=2.75$ ) respectively for the intervals from $7 \mathrm{~h} 00$ to $8 \mathrm{~h} 30,9 \mathrm{~h} 30$ to $11 \mathrm{~h} 00,13 \mathrm{~h} 00$ to $14 \mathrm{~h} 30$ and $15 \mathrm{~h} 30$ to $17 \mathrm{~h} 00$.

Determination coefficients showed the estimated regression equations explained $91 \%$ of data variation for the number of total visits of $A$. mellifera on sunflower crops, suggesting a high reliability in the estimates. By means of estimated regression equations, it was observed that the average value total of bees per capitulum in days of highest number of visits for each time interval were 2.94 (from 7 h00 to 08h30), 2.50 (from $9 \mathrm{~h} 30$ to $11 \mathrm{~h} 00$ ), 2.27 (from $13 \mathrm{~h} 00$ to $14 \mathrm{~h} 30$ ) and 2.40 visits (from $15 \mathrm{~h} 30$ to $17 \mathrm{~h} 00$ ).

The average number of visits of $A$. mellifera per capitulum in hybrids Helio 360 and Aguará did not differ on the third flowering day. These hybrids had higher mean bee values per capitulum $(p \leq 0.05)$ than those of Helio 251 and Charrua, which showed similar averages. The variety Multissol differed $(p \leq 0.05)$ from the others and had fewer visits of $A$. mellifera per capitulum (Table 1).

There was a positive open pollination effect on the seed yield regardless of the genotype studied. The estimated average yield of seeds in open pollinated sunflowers was 3840.9 \pm 725.5 seed. This was $43 \%$ higher $(p \leq 0.05)$ compared to the estimated average yield of seeds for plants of the same genotypes in restricted pollination $(2683.3 \pm 1011.7$ seed $)$. The variation coefficient was $15.51 \%$.

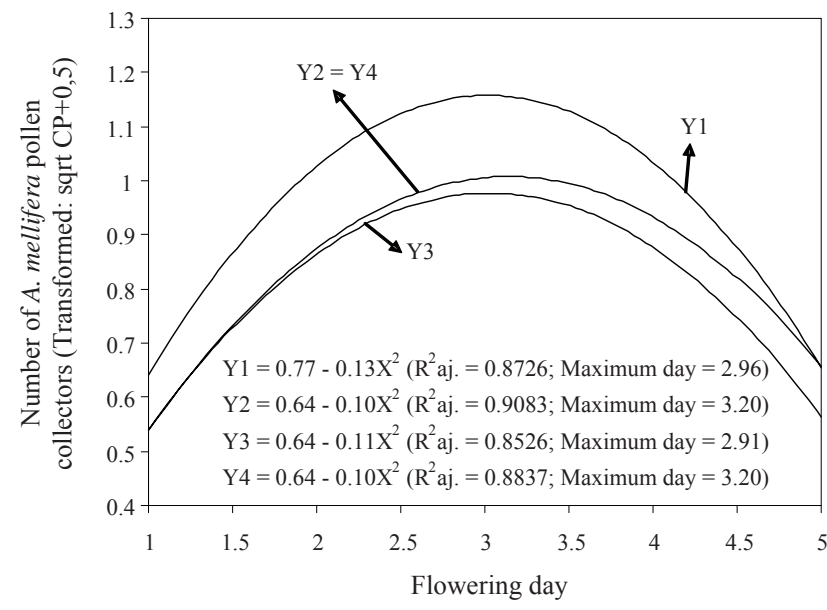

Figure 3 - Regression curves of the total number of $A$. mellifera pollen collectors (Y1, Y2, Y3 and Y4) as a function of sunflower flowering day for each time interval ( $7 \mathrm{~h} 00$ to $8 \mathrm{~h} 30$; $9 \mathrm{~h} 30$ to $11 \mathrm{~h} 00 ; 13 \mathrm{~h} 00$ to $14 \mathrm{~h} 30$; and $15 \mathrm{~h} 30$ to $17 \mathrm{~h} 00$ ).

\section{Discussion}

The highest number of visits to flowers head (capitulum) occurred between the second and third days of flowering (Figure 1), possibly because flowers in the middle region of the capitulum came into floral anthesis. This part of the capitulum area has the largest amount of nectar production (Pinzauti and Frediani, 1985).

In this study, the average temperature and humidity was $26{ }^{\circ} \mathrm{C}$ and $65 \%$ and minimum and maximum values registered were $20.1{ }^{\circ} \mathrm{C}$ and $31 \%$ and $35.1{ }^{\circ} \mathrm{C}$ and $97 \%$, respectively, during the five day bloom period. Although there was variation in relative temperature and humidity between the experimental days, these causes of variation were not enough to prevent the occurrence of the significance of the factor time (days) in bee visitation. This variation is seen as an outlier on the variance analysis. On the other hand, other authors observed an increased visitation of bees on sunflower capitula when the flowering period coincided with lower temperatures and higher relative humidity, which is the opposite of what is stated above (DeGrandi-Hoffmann and Chambers, 2006). In certain situations, weather conditions can interfere in the rate of opening on capitula flowers, flight behavior, nectar collection, and bee visitation during the experimental period (Morgado et al., 2002). Also, plants will decrease the amount of nectar they secrete when temperatures are high, and thus the florets are less attractive to bees (Ribbands, 1953). Therefore, data regarding an increased visitation of bees on this study will be restricted to tested sunflower genotypes, i.e., that have high adaptability to various weather conditions existing in Brazil and temperature rates recorded during the flowering period.

The highest number of nectar and pollen collector bees occurred in the morning between 7 h00 to 8 h30 (Figure 2, 3). Highest number of visits in sunflower crops was observed to be between $14 \mathrm{~h} 15$ to $15 \mathrm{~h} 15$ (Teixeira and Zampieron, 2008). Foraging activity by $A$. mellifera in sunflowers occurred the whole day with peaks of visits for collecting pollen and nectar at $9 \mathrm{~h} 00$ and $14 \mathrm{~h} 00$, respectively (Paiva et al., 2002). Morgado et al. (2002) detected a reduction in foraging activity of Africanized honeybees in sunflower crop after $10 \mathrm{~h} 00$ and increase after 16h00. However, Santana et al. (2002) observed a high occurrence of $A$. mellifera at $8 \mathrm{~h}$, with minor fluctuations during the rest of the day.

In this study, nectar-collecting bees preferred to carry out their foraging activities in the mildest periods of morning and afternoon, i.e., greater thermal comfort, considering the high

Table 1 - Average number of visits of Apis mellifera per capitulum in five sunflower genotypes, during the flowering period.

\begin{tabular}{lccccc}
\hline Genotypes & Day 1 & Day 2 & Day 3 & Day 4 & Day 5 \\
\hline Helio 360 & $1.19(1.30) \mathrm{a}$ & $2.29(1.67) \mathrm{a}$ & $3.40(1.97) \mathrm{a}$ & $2.16(1.63) \mathrm{a}$ & $0.46(0.98) \mathrm{ab}$ \\
Multissol & $0.36(0.93) \mathrm{c}$ & $1.46(1.40) \mathrm{b}$ & $1.61(1.45) \mathrm{c}$ & $0.98(1.22) \mathrm{c}$ & $0.36(0.93) \mathrm{ab}$ \\
Helio 251 & $0.46(0.98) \mathrm{bc}$ & $1.98(1.57) \mathrm{ab}$ & $2.26(1.66) \mathrm{b}$ & $1.63(1.46) \mathrm{ab}$ & $0.26(0.87) \mathrm{bc}$ \\
Charrua & $0.56(1.03) \mathrm{bc}$ & $2.03(1.59) \mathrm{ab}$ & $2.85(1.83) \mathrm{b}$ & $1.39(1.37) \mathrm{bc}$ & $0.73(1.11) \mathrm{a}$ \\
Aguará & $0.82(1.15) \mathrm{ab}$ & $2.16(1.63) \mathrm{a}$ & $3.40(1.97) \mathrm{a}$ & $1.03(1.24) \mathrm{c}$ & $0.26(0.87) \mathrm{bc}$ \\
\hline
\end{tabular}

Means followed by different letters in the column differ (Tukey-Kramer, $p<0.05$ ). Average values in parentheses represent transformed data $(\mathrm{X}+0.5)^{1 / 2}$. 
temperatures registered during the experimental period. Due to climatic conditions, especially high temperatures, the water content in nectar evaporates faster (Cobert et al., 1979). Zajácz et al. (2008) reported the availability of nectar in sunflower is influenced by relative humidity and rainfall during the flowering period, in addition to temperature. Thus, the lowest number of visits by $A$. mellifera to collect nectar in the afternoon is probably due to resource availability.

Regarding pollen collecting, sunflower is a species that has anther dehiscence in the morning, and therefore, pollen collecting bees carry out their activities during this period (Free, 1993). This explains the higher number of pollen collection in the morning found in this study.

Nectar collecting bees were more frequent (on average 2.28 bees per capitulum) than pollen collecting bees (on average 0.40 bees per capitulum) during days and at peak visitation in sunflower cultivation (Figures 2 and 3). These results corroborate those observed by Paiva et al. (2002) and Teixeira and Zampieron (2008) who stressed nectar collecting Africanized bees exercised greater influence on sunflower pollination than pollen on nectar/pollen collecting bees. Bees that collect nectar tend to discard pollen stuck on their pollen basket while still the capitulum of sunflowers, causing indirect pollination (Free, 1993). Moreover sunflower pollen is little attractive for bees (Basualdo et al., 2000). Thus, nectar produced by sunflower's flowers can be important the strategy of attracting and maintaining $A$. mellifera in cultivated areas, as well as by contributing to increased production of honey for exploitation by beekeepers (Machado and Carvalho, 2006).

The density of $A$. mellifera observed showed that the mean value estimated from 2.27 to $2.94 \mathrm{~A}$. mellifera per capitulum, on time and days of highest number of visits was satisfactory to increase the yield of sunflower seeds. Moreti et al. (1996) found during sunflower Anhandy flowering time the average number of 5.3 visits of $A$. mellifera per capitulum. According to the same authors, the density obtained generated increase of the number of free seeds in pollinators by $86 \%$, as compared to the plants that were restricted to pollinators.

It seems convincing that a saturation of bees in the culture seems to be satisfactory for the increase in the production of sunflower seeds. However, there not is a general recommendation regarding the density of bees to be used in programs of pollination, due to variations among different cultivars and local conditions; however, colonies should be close to the crop (Antunes et al., 2007). Moreover, the combination of $A$. mellifera and other bee species results in improvement of pollination in sunflower hybrids (DeGrandi-Hoffman and Watkins, 2000). Interactions between wild and honey bees increased five times the bee's efficiency pollination in sunflower hybrid (Greenleaf and Kremen, 2006). The same authors commented that indirect participations caused by interactions among bees species were five times most important than direct contributions of wild bees in sunflower pollination. Africanized bees are more efficient and have higher fidelity than European bees in pollen collection in sunflower (Basualdo et al., 2000). Therefore, studies about natural pollinators efficiency and interactions with introduced species in agricultural areas are very important to economic variability of pollination programs. These aspects may contribute the determination of ideal number of bee colonies to be introduced in cultures, especially the sunflower, generating good profits.

The average values of $A$. mellifera per capitulum (Table 1) showed differences in bees' attractiveness to sunflower genotypes tested in this study. DeGrandi-Hoffman and Chambers (2006) found differences on average of bees' number per capitulum in cultivars of sunflowers. According the same authors this was affected by cultivars, planting season and interaction among them. Pham-Delegue et al. (1990) suggested differences in sugar concentration in the nectar of plants can be used by foragers bees as discriminating factor for selecting the best food source. Martins et al. (2005) studied the attractiveness of sunflower plants and found applications of sucrose solutions positively influenced his attractiveness, with number of bee visits four times greater than in his control. Thus, the biggest number of bees observed in Helio 360 and Aguará sunflower hybrids when compared to the Helio 251, Charrua and Multissol genotypes may have been caused by differences in attraction between the genotypes tested in this study. In this research we did not analyze the availability of nectar from the plants along the flowering period. However, one can argue that there are differences in the amount and concentration of the sugar in the nectar secreted, as well as the availability of pollen throughout the day.

Although honey bee foraging activity was greater on some genotypes, seed set did not differ among open-pollinated capitula. These results indicate that the differences in foraging activity among genotypes probably were not great enough to the point of reflecting differences in the production of seeds in the open-pollinated capitula to the different genotypes.

The identification of differences in attractiveness to pollinators to hybrid sunflowers can be decisive in increasing the yield of plant species dependent on these biotic agents for reproduction, in addition to providing support to plant breeders in genetic selection of more productive strains (DeGrandi-Hoffman and Watkins, 2000), the overall result should be an increase in the number of visits by pollinators to increase agricultural output.

The productivity of seeds on free plants pollinators was 43 $\%$ higher $(p \leq 0.05)$ related to restricted of insect pollination. These results corroborate those found by Du Toit (1990), Nderitu et al. (2008) and Oz et al. (2009), who observed increasing on production of sunflower's seed in area with introduction of Africanized bees of $38 \%, 53 \%$ and $206 \%$, respectively, related areas without bees.

Our results confirmed previous results of higher production of seeds in sunflowers with introduction of colonies of bees in culture. Increasing on productivity may be related to foraging behavior of Africanized A. mellifera. These bees, unlike other species, perform lengthy visits, touching anthers and stigmas of flowers, promoting flies on flower which allow the fall of many pollen grains on the stigma, as well as performing visits at times that flowers are abundantly filled with pollen (Alves and Freitas, 2006). Therefore, the introduction of Africanized honeybees on agricultural crops, especially in sunflower cultivation, is an alternative to increase seed production, mainly in agricultural areas where natural pollinators are scarce. 


\section{Acknowledgements}

To Araucaria Foundation to Support the Scientific and Technological Development of Paraná.

\section{References}

Alves, J.E.; Freitas, B.M. 2006. Foraging behavior and pollination efficiency of five bee species on guava (Psidium guajava L.) flowers. Revista Ciência Agronômica 37: 216-220 (in Portuguese, with abstract in English).

Antunes, O.T.; Calvete, E.O.; Rocha, H.C.; Nienow, A.A.; Cecchetti, D.; Riva, E.; Maran, R.E. 2007. Yield of strawberry cultivars polinized by jatai bees under protected environment. Horticultura Brasileira 25: 94-99 (in Portuguese, with abstract in English).

Basualdo, M.; Bedascarrasbure, E.; Jong, D. 2000. Africanized honey bees (Hymenoptera: Apidae) have a greater fidelity to sunflowers than European bees. Journal of Economic Entomologic 93: 304-307.

Brazil. Department of Agriculture. 2004. Seed rules for production, trading and use; Law n 10.711, of August 5, decree $n^{\circ}$ 5.153, of July 23, 2004. MAPA/SNPC, Brasília, DF, Brazil (in Portuguese).

Campos, M.S.O.; Sader, R. 1987. Effect of potassic on the production and seed quality of sunflower. Revista Brasileira de Sementes 9: 19-27 (in Portuguese, with abstract in English).

Cobert, S.A.; Willmer, P.G.; Beament, J.W.L.; Unwin, D.M., Preys-Jones, O.E. 1979. Post-secretory determinants of sugar concentration in nectar. Plant Cell and Environment 2: 293-308.

DeGrandi-Hoffman, G.; Martin, J.H. 1995. Does a honey bee (Apis mellifera) colony foraging population on male-fertile sunflowers (Helianthus annuus) affect the amount of pollen on nest mates foraging on male-sterile? Journal of Apicultural Research 34: 109-114.

DeGrandi-Hoffman, G.; Watkins, J.C. 2000. The foraging activity of honey bees Apis mellifera and non-Apis bees on hybrid sunflower (Helianthus annuus) and its influence on cross-pollination and seed set. Journal of Apicultural Research 39: 37-45.

DeGrandi-Hoffman, G.; Chambers, M. 2006. Effects of honey bee (Hymenoptera: Apidae) foraging on seed set in self-fertile sunflowers (Helianthus annuus L.). Environmental Entomology 35: 1103-1108.

Du Toit, A.P. 1990. The importance of certain insects as pollinators of sunflower (Helianthus annuus L.). South African of Plant and Soil 7: 159-162.

Free, J.B. 1993. Insect Pollination of Crops. 2ed. Academic Press, London, $\mathrm{UK}$.

Greenleaf, S.S.; Kremen, C. 2006. Wild bees enhance honey bees pollination of hybrid sunflower. Proceedings of the National Academy of Sciences 37: 13890-13895.

Machado, C.S.; Carvalho, C.A.L. 2006. Bees (Hymenoptera: Apoidea) on sunflower flowers in Recôncavo Baiano region, Brazil. Ciência Rural 36: 1404-1409 (in Portuguese, with abstract in English).

Martins, E.A.C.; Machado, R.J.P.; Lopes, J. 2005. Honeybees attractant in hybrid colored sunflower seed production crop. Semina: Ciências Agrárias 26: 489-494 (in Portuguese, with abstract in English).

McGregor, S.E. 1976. Insect Pollination of Cultivated Crop Plants. USDA, Washington, DC, USA.

Moreti, A.C.C.C.; Silva, R.M.B.; Silva, E.C.A.; Alves, M.L.T.M.F.; Otsuk, I.P. 1996. Increase of sunflower (Helianthus annuus) seed production by pollinating insect action. Scientia Agricola 53: 2-3 (in Portuguese, with abstract in English).
Morgado, L.N.; Carvalho, C.F.; Souza, B.; Santana, M.P. 2002. Fauna of bees (Hymenoptera: Apoidea) on sunflower flowers, Helianthus annuus L., in Lavras - MG. Ciência Agrotecnologia 26: 1167-1177 (in Portuguese, with abstract in English).

Müller, A.; Diener, S.; Schnyder, S.; Stutz, K.; Sedivy, C.; Dorn, S. 2006. Quantitative pollen requirements of solitary bees: implications for bee conservation and the evolution of bee-flower relationships. Biological Conservation 130: 604-615.

Nderitu, J.; Nyamasyo, G.; Kasina, M.; Oronje, M.L. 2008. Diversity of sunflower pollinators and their on seed yield in Makueni District, Eastern Kenya. Spanish Journal of Agricultural Research 6: 271-278.

Oz, M.; Karasu, A.; Cakmak, I.; Goksoy, A.T.; Turan, Z.M. 2009. Effects of honey bee (Apis mellifera) pollination on seed set in hybrid sunflower (Helianthus annuus L.). African Journal of Biotechnology 8: 10371043.

Paiva, G.J.; Terada, Y.; Toledo, V.A.A. 2002. Behavior of Apis mellifera L. Africanized honeybees in sunflower (Helianthus annuus L.) and evaluation of Apis mellifera L. colony inside covered area of sunflower. Acta Scientiarum 24: 851-855.

Pham-Delegue, M.H.; Etievant, P.; Ghuichard, E.; Marilleau, R.; Doualt, P.H.; Chauffaille, J.; Masson, C. 1990. Chemicals involved in honeybeesunflower relationship. Journal of Chemical Ecology 16: 3053-3065.

Pinzauti, M.; Frediani, D. 1985. Factors determining nectar secretion from Helianthus annuus L. and related observations about the behavior of foraging insects. Apicoltura 1: 179-192.

Porto, W.S.; Carvalho, C.G.P.; Pinto, R.J.B. 2007. Adaptability and stability as selection criteria for sunflower genotypes. Pesquisa Agropecuária Brasileira 42: 491-499 (in Portuguese, with abstract in English).

Ribbands, C.R. 1953. The Behaviour and Social Life of Honeybees. Bee Research Association, London, UK.

Santana, M.P.; Carvalho, C.F.; Souza, B.; Morgado, L.N. 2002. Bees (Hymenoptera: Apoidea) visiting bean flowers, Phaseolus vulgaris L., in Lavras and Ijaci-MG. Ciência e Agrotecnologia 26: 1119-1127 (in Portuguese, with abstract in English).

Teixeira, L.M.R.; Zampieron, S.L.M. 2008. Phenology, floral biology studies of the sunflower (Helianthus annuus, Compositae) and associated flower visitors, in different seasons of the year. Ciência et Práxis 1: 5-14 (in Portuguese, with abstract in English).

Thomazini, M.J.; Thomazini, A.P.B.W. 2002. Bee diversity (Hymenoptera: Apoidea) in inflorescences of Piper hispidinervum (C.DC). Neotropical Entomology 31: 27-34 (in Portuguese, with abstract in English).

Universidade Federal de Viçosa [UFV]. 2003. System of Statistical Analysis and Genetic - SAEG, Version 8.1. FEPMVZ, Viçosa, MG, Brazil (in Portuguese).

Vrânceanu, A.V. 1977. Sunflower. Mundi Prensa, Madrid, Spain (in Spanish).

Zajácz, E.; Szalai, T.; Mészáros, G. 2008. Evaluation of the apicultural value of sunflower hybrids. Acta Agronomica Hungarica 56: 91-97.

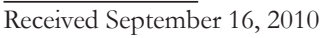

Accepted May 13, 2011 